\title{
Influence of Acidity and Extraction Time on the Recovery of Flavonoids from Grape Skin Pomace Optimized by Response Surface Methodology
}

\author{
P. Putnik, ${ }^{a}$ D. Bursać Kovačević, a," M. Radojčin,, \\ and V. Dragović-Uzelac ${ }^{a}$ \\ aFaculty of Food Technology and Biotechnology, \\ University of Zagreb, Pierottijeva 6, 10000 Zagreb, Croatia \\ bUniversity of Novi Sad, Trg Dositeja Obradovica 8, \\ 21000 Novi Sad, Republic of Serbia
}

doi: 10.15255/CABEQ.2016.914

Original scientific paper

Received: June 7, 2016

Accepted: December 5, 2016

\begin{abstract}
Grape pomace is recognized as an economical source for the recovery of a large number of biologically active compounds, such as polyphenols. Grape pomace extracts can be successfully used as raw material for functional foods production, since they are generally recognized as safe for the food industry. This study aimed to quantify the amounts of recovered flavonoids (total flavonoids, proanthocyanidins, anthocyanins, and flavonols) from grape skin pomace (Vitis vinifera L. cv. Merlot) under conventional extraction with different acidities $(0.5 \%-1 \% \mathrm{HCl})$ and lengths of extraction time (30-60 minutes). The grand average values in this study were as follows: (i) proanthocyanidins $12.08 \pm 0.25 \mathrm{mg} \mathrm{CE} \mathrm{g}^{-1}$ d.m., (ii) anthocyanins $2.17 \pm 1.02 \mathrm{mg} \mathrm{Mvd-3-glc} \mathrm{g}{ }^{-1}$ d.m., (iii) flavonols 7.73 $\pm 0.11 \mathrm{mg} \mathrm{QE} \mathrm{g}{ }^{-1}$ d.m., and (iv) total flavonoids $36.28 \pm 0.42 \mathrm{mg} \mathrm{QE} \mathrm{g}^{-1}$ d.m. The amounts of studied polyphenols generally increased with acidity and length of extraction time. This relation was more evident for flavonols and total flavonoids, while less clear for other examined phenolics.
\end{abstract}

Key words:

total flavonoids, proanthocyanidins, anthocyanins, flavonols, optimal extraction acidity/time, grape pomace skin extracts

\section{Introduction}

In 2012, grape production amounted to a total of 77 million tons ${ }^{1}$, and $80 \%$ of all produced grape was used for winemaking ${ }^{2}$. Twenty percent of the grape in wine production accounts for by-products, such as grape pomace ${ }^{3}$, totaling nearly 11 million tons of grape by-products per year (other recent sources reported pomace production of 5-14 million tons $)^{4}$. Overproduction of grape pomace can be challenging for industrial waste management ${ }^{5}$, or it can be prudently used as a valuable raw material for functional food production ${ }^{6}$. The functional foods can be engineered from any sources ${ }^{7}$. Hence, as expected, this type of food market has the fastest growth rate in the world, suggesting that interest for processing raw materials such as grape pomace will only increase in the future . $^{8}$

Grape pomace from most grape varieties (with both seeds and skins) are recognized as an economical source for the recovery of a large number of biologically active compounds (BAC), primarily polyphenols ${ }^{4,9}$. Polyphenols such as flavonoids, phenolic acids, phenolic alcohols, stilbenes, and lig-

"Corresponding author: E-mail: dbursac@pbf.hr;

Phone: +385 (1) 4605009; Fax: +385 (1) 4605072 nans, are the main phenolic compounds found in pomace $^{10}$. From this group of BAC, the most interesting polyphenols are flavonoids, as they are known to contribute to human health via their antioxidative property ${ }^{10-12}$. For instance, literature reports that flavonoids (flavonols, isoflavones, anthocyanins, flavanols, flavones, and flavanones) in general have beneficial effects on atherosclerosis, hypertension, neurodegeneration, myocardial, and other medical conditions ${ }^{10}$. Additionally, flavonoids extracted from grapes exhibit anti-inflammatory, antibacterial, antiallergic, anticancer, and antioxidative potentia $1^{10}$. The proanthocyanidins, also known as oligomeric flavonoids, have great importance in nutrition and medicine because of their antioxidant activity, which is much higher than that of monomeric phenolics. Literature reports their possible effects on reducing the risk of chronic diseases, such as cardiovascular disease and cancer ${ }^{13}$. Therefore, evaluating the influences of extraction parameters on flavonoids recovered from grape pomace is essential for the nutritive and commercial value of the grape extracts.

Commonly, the objective of an extraction is to optimally recover the greatest possible amount(s) of targeted compound(s) with minimum contamination with undesirable components in the obtained ex- 
tract(s). Phytochemicals such as flavonoids are commonly recovered from plants by solid-liquid extraction ${ }^{14}$. Extraction of target compounds from grape pomace is mainly affected by grape variety/ vintage, type of extraction/solvent, acidity, temperature, time, addition of enzymes, and particle size ${ }^{14}$ ${ }^{20}$. Ethanol is generally recognized as safe (GRAS status), and is commonly used as organic solvent in conventional extraction of polyphenols ${ }^{21}$. Increased temperature improves extraction due to better diffusion and disruption of plant cellular structures ${ }^{14,21}$. Increased acidity induced by the use of strong acids, such as $\mathrm{HCl}$, with elevated temperatures, tends to shorten the extraction time of polyphenols (e.g. flavonoids). This is due to the denaturation of grape cellular membranes, thus promoting their release from the pomace matrix ${ }^{22}$. It has previously been shown that increased acidity supports extraction of phenolic acids and total phenols together with increased antioxidant capacity of extracts ${ }^{23}$. Extraction time varies with regards to different plant material and particle sizes, where smaller particles of plant material tend to reduce extraction time ${ }^{14}$. Due to these numerous sources of variation, it is important to quantify those influences that have an effect on the amount of extracted flavonoids in different grape pomaces. The food industry has shown increased interest for the development and evaluation of natural antioxidants ${ }^{24}$. As mentioned previously, flavonoids from grape pomace are important contributors to antiradical activity in grape extracts. Hence, it is essential for health benefits and commercial value of functional foods to evaluate the major contributors of antioxidant activity.

Therefore, the objectives of this study were as follows: (i) to quantify the amounts of recovered flavonoids (total flavonoids, proanthocyanidins, anthocyanins, and flavonols) at different acidity and lengths of extraction time from red grape skin pomace; (ii) to quantify the cumulative influences of extraction time and acidity on flavonoids from objective (i); and (iii) to optimize extraction parameters with regard to the investigated flavonoid subgroups.

\section{Materials and methods}

\section{Chemicals and standards}

Ethanol, methanol, hydrochloric acid, aluminum chloride, potassium acetate, sulfuric acid, potassium chloride, sodium acetate, and ascorbic acid were of reagent grade, purchased from Gram-mol (Zagreb, Croatia). Sodium carbonate was purchased from Lach-Ner (Czech Republic). Gallic acid, quercetin, $(+)$-catechin hydrate and vanillin were obtained from (Sigma Aldrich Chemie GmbH, Germany). Folin-Ciocalteu reagent was purchased from Kemika (Zagreb, Croatia).

\section{Plant materials}

This study was carried out with grape pomace by-products obtained from the Merlot red grape cultivar (Vitis vinifera L.). The samples were provided by the winemaking company Agrolaguna (Poreč, Croatia) during the 2014 harvest. The grape pomace was collected on the harvesting day after destemming, pressing, filtering of the grapes, and freeze-drying. Firstly, $500 \mathrm{~g}$ of grape pomace was frozen at $-60{ }^{\circ} \mathrm{C}$, then freeze-dried in a laboratory freeze-dryer (CoolSafe PRO, Labogene, Denmark) under high vacuum $(0.13-0.55 \mathrm{hPa})$ for $24 \mathrm{~h}$ with isothermal (heating) plate temperatures of $20{ }^{\circ} \mathrm{C}$. The final water content of the dried grape pomace was $3.15 \%$. The freeze-dried grape pomace was stored in the dark in polyethylene bags at $-18{ }^{\circ} \mathrm{C}$ until analysis. Prior to analysis, the skins and seeds were manually separated from the thawed grape pomace, and the grape skins were used for further analysis. The grape skins were then milled and pulverized into powder with a blender (Imetec Dolcevita CG1, 150W) and used for extraction. Powder particle size distribution was: $\mathrm{d}(0.9) \leq 6 \pm 1 \mathrm{~mm}$; $\mathrm{d}(0.5) \leq 3 \pm 1 \mathrm{~mm} ; \mathrm{d}(0.1) \leq 2$ (Malvern, Mastersizer 2000 particle size analyzer, Germany).

\section{Conventional extraction}

The extraction conditions (solvent polarity, addition of acid, extraction time, extraction temperature) were chosen from previously published literature $^{25-27}$. Hence, the extraction method for recovering phenolic compounds from grape skin pomace was done using $50 \%$ aqueous ethanol (v/v) with 12 mol L ${ }^{-1}$ hydrochloric acid $(0,0.5$, and $1 \%)$. The samples $(0.3 \mathrm{~g})$ of the grape pomace skins were weighed into Erlenmeyer flasks and extracted with $20 \mathrm{~mL}$ of solvent for 30,45 , and 60 min after flushing with nitrogen, in order to prevent oxidation during extraction. The extraction process was carried under heat-reflux at $80{ }^{\circ} \mathrm{C}$ with magnetic stirrer. The extraction of each sample was done twice. The samples were then filtered through Whatman filter paper No. 40 (Whatman International Ltd., Kent, UK), and made up to $25 \mathrm{~mL}$ in volumetric flask with extraction solvent. Prior to analysis, the extracts were stored at $-18{ }^{\circ} \mathrm{C}$ in an inert gas atmosphere.

\section{Determination of total flavonoids}

Total flavonoids (TF) were determined according to the method described in literature ${ }^{28}$. A volume of $0.5 \mathrm{~mL}$ of extract was added to $1.5 \mathrm{~mL}$ of 96 $\%$ ethanol (v/v), $0.1 \mathrm{~mL}$ of $10 \%$ aluminum chloride $(\mathrm{m} / \mathrm{v}), 0.1 \mathrm{~mL}$ of $1 \mathrm{~mol} \mathrm{~L}^{-1}$ potassium acetate, and $2.8 \mathrm{~mL}$ of distilled water. After thorough mixing, the reaction mixtures were incubated at room temperature for $30 \mathrm{~min}$, followed by absorbance readings at $415 \mathrm{~nm}$. The amount of $10 \%$ aluminum 
chloride was substituted by the same amount of distilled water in blank. The calibration curve was prepared using 10 to $75 \mathrm{mg} \mathrm{L}^{-1}$ of quercetin in methanol (linear regression $r^{2}=0.9971$ ). The concentration of $\mathrm{TF}$ was expressed as $\mathrm{mg}$ quercetin equivalents (QE) $g^{-1}$ dry matter.

\section{Determination of polymeric proanthocyanidins}

Polymeric proanthocyanidins (PCs) were estimated spectrophotometrically according to vanillin assay $^{29}$. A $2.5 \mathrm{~mL}$ aliquot of a freshly prepared solution of $1 \%$ vanillin $(\mathrm{m} / \mathrm{v})$ and $25 \%$ sulfuric acid $(\mathrm{v} / \mathrm{v})$, both in $100 \%$ methanol, were added to $1 \mathrm{~mL}$ of extract. The mixture was kept at $20^{\circ} \mathrm{C}$ in a water bath, and after $15 \mathrm{~min}$, the absorbance at $500 \mathrm{~nm}$ was read. The calibration curve was prepared using 50 to $400 \mathrm{mg} \mathrm{L}^{-1}$ of catechin in methanol (linear regression $r^{2}=0.9961$ ). The concentration of PCs was expressed as $\mathrm{mg}$ catechin equivalents $(\mathrm{CE}) \mathrm{g}^{-1}$ dry matter.

\section{Determination of anthocyanin content}

Anthocyanin content (ACY) was measured by the $\mathrm{pH}$ differential method ${ }^{30}$. The extract was diluted to the same extent in $0.025 \mathrm{~mol} \mathrm{~L}^{-1}$ potassium chloride ( $\mathrm{pH} 1.0)$ and $0.4 \mathrm{~mol} \mathrm{~L}^{-1}$ sodium acetate $(\mathrm{pH} 4.5)$. The mixtures were measured spectrometrically at both 520 and $700 \mathrm{~nm}$. Anthocyanin content (mg Mvd-3-glu equivalents $\mathrm{g}^{-1}$ dry matter) was calculated as $\left(\left(A_{520, \mathrm{pH} 1.0}-A_{700, \mathrm{pH} 1.0}\right)-\left(A_{520, \mathrm{pH} 4.5}-\right.\right.$ $\left.\left.A_{700, \mathrm{pH} 4.5}\right)\right) \cdot 529 \cdot$ dilute factor $\cdot 1000 / 28000$, where the molar absorptivity and molar mass of malvidin-3-glucoside (Mvd-3-glc) were 28,000 $\mathrm{L} / \mathrm{cm} / \mathrm{mol}$ and $529 \mathrm{~g} \mathrm{~mol}^{-1}$, respectively.

\section{Determination of flavonols content}

Flavonols content (FL) was measured by using the method from literature ${ }^{31}$. The grape skin pomace extracts $(0.25 \mathrm{~mL})$ were mixed with $0.25 \mathrm{~mL}$ of 1 $\mathrm{g} \mathrm{L}^{-1} \mathrm{HCl}$ in aqueous ethanol $(96 \%, \mathrm{v} / \mathrm{v})$, and 4.55 $\mathrm{mL}$ of $2 \mathrm{~g} \mathrm{~L}^{-1} 12 \mathrm{~mol} \mathrm{~L}^{-1} \mathrm{HCl}$. The absorbance of the reaction mixture was then read at $360 \mathrm{~nm}$. Standard curve of quercetin $\left(100 \mathrm{mg} \mathrm{L}^{-1}\right)$ dissolved in aqueous methanol $(80 \%, \mathrm{v} / \mathrm{v})$ was used to quantify HCA, and the results were expressed as mg of caffeic acid equivalents $\mathrm{g}^{-1}$ (on a fw basis). The calibration curve was prepared using 10 to $100 \mathrm{mg} \mathrm{L}^{-1}$ of quercetin in methanol (linear regression $r^{2}=$ 0.9989). The concentration of FL was expressed as mg quercetin equivalents $(\mathrm{QE}) \mathrm{g}^{-1}$ dry matter.

\section{Experimental methodology and statistical analysis}

As before, the experiments were designed as full factorial randomized experimental design (Ta-
Table 1 - Experimental design runs for investigated extraction parameters

\begin{tabular}{ccc}
\hline Grape skin extracts & Extraction time [min] & $\mathrm{HCl}[\%]$ \\
\hline A1 & 30 & 0 \\
A2 & 30 & 0.5 \\
A3 & 30 & 1 \\
A4 & 45 & 0 \\
A5 & 45 & 0.5 \\
A6 & 45 & 1 \\
A7 & 60 & 0 \\
A8 & 60 & 0.5 \\
A9 & 60 & 1 \\
\hline
\end{tabular}

ble 1$)^{32}$. Dependent variables for multivariate analysis were: amounts of proanthocyanidins, anthocyanins, flavonols, and flavonoids in $\mathrm{mg} \mathrm{g}^{-1}$ dry matter. Independent variables were: extraction time/min and $\mathrm{HCl}$ acidity $/ \%$. Descriptive statistics was used to assess basic information about the experimental dataset (e.g. to obtain sample basic metrics, check for normality of distribution). Normality and homoscedasticity was tested with Kolmogorov-Smirnov and Levene's test, and statistical methods for analysis were chosen based on recommendations from literature ${ }^{33}$. Continuous variables were analyzed by multivariate analysis of variance. Pearson's linear correlation tests were used to assess the relation between the pairs of continuous variables. Lack-of-fit tests were used to evaluate predictive power of models (i.e. modeling efficacy). The significance levels for all tests were $\alpha \leq 0.05$. Analyses were performed with IBM SPSS Statistics (v.20). The RSM optimization analysis was done with STATGRAPHICS Centurion XVII.

\section{Results and discussion}

\section{Influence of extraction parameters on concentrations of proanthocyanidins}

Recently, the recovery of phenolic compounds from food processing waste has been receiving increased attention as a potentially low-cost and valuable source of new and effective antioxidants ${ }^{23}$. Various novel techniques have been employed to recover phenolics from plant matrices, but from the industrial point of view, conventional solvent extraction is usually preferred due to its process simplicity, efficiency, and lower investment $\cos \mathrm{t}^{19,20,34-40}$.

The type and polarity of extraction solvent play an important role in the extraction selectivity and efficiency, where ethanol and water are preferred 
solvents since they are non-toxic and environmentally friendly. In the present study, an aqueous mixture of ethanol $(50 \%, \mathrm{v} / \mathrm{v})$ was chosen since $50 \%$ aqueous solvent was found to be the optimum concentration for the extraction of phenolic compounds from grape by-products ${ }^{21,41}$.

Table 2 lists the concentrations of proanthocyanidins, anthocyanins, flavonols, and total flavonoids in grape pomace skin extracts studied at three extraction times with or without addition of $\mathrm{HCl}$.

The grand average for proanthocyanidins in grape skin pomace extracts was $12.08 \pm 0.25 \mathrm{mg} \mathrm{CE}$ $\mathrm{g}^{-1}$ d.m. Similar results $\left(17.73 \pm 2.5 \mathrm{mg} \mathrm{g}^{-1}\right.$ d.m.) were previously reported in red grape pomaces from five grape cultivars ${ }^{42}$. The differences in results were likely attributed to the use of different extraction techniques (ultrasound bath), however, the authors used somewhat similar parameters as in this study (use of $0.1 \% \mathrm{HCl}$ with $70 \%$ acetone at 45 $\left.{ }^{\circ} \mathrm{C}\right)$. It can be observed that the extraction yield of proanthocyanidins is significantly higher with addition of $\mathrm{HCl}$, but remained the same in $0.5-1 \% \mathrm{HCl}$ interval. With regards to extraction time, it can be seen that the concentrations of proanthocyanidins did not significantly change from 30 to 60 minutes. This trend was observed for all combinations of time and percentages of $\mathrm{HCl}$ (Table 2). It was already shown that acidic solvent increased yields of proanthocyanidins solubilized from the grains of some sorghum varieties ${ }^{43}$. Proanthocyanidins are stable at $\mathrm{pH} 4-6$, and acid assists in dissociation of proanthocyanidins from the plant matrix ${ }^{44}$. Comparing the contents of polymeric procyanidins from literature of $13.4 \mathrm{mg} \mathrm{g}^{-1} \mathrm{~d} . \mathrm{m}^{45}$, the grape skin pomace from this study represents a potentially valuable source of phenolic compounds.

Table 2 - Single and cumulative influences of acidity addition and extraction time on content of total flavonoids, proanthocyanidins, anthocyanins, and flavonols in grape skin pomace extracts*

\begin{tabular}{|c|c|c|c|c|}
\hline Extraction parameters & Total flavonoids & Proanthocyanidins & Anthocyanins & Flavonols \\
\hline $\mathrm{HCl}(\%)$ & $p \leq 0.01^{\dagger}$ & $p \leq 0.01^{\dagger}$ & $p \leq 0.01^{\dagger}$ & $p \leq 0.01^{\dagger}$ \\
\hline 0 & $20.63 \pm 0.73^{\mathrm{a}}$ & $7.84 \pm 0.43^{\mathrm{a}}$ & $1.52 \pm 0.18^{\mathrm{a}}$ & $4.53 \pm 0.19^{\mathrm{a}}$ \\
\hline 0.5 & $41.43 \pm 0.73^{b}$ & $13.73 \pm 0.43^{b}$ & $2.54 \pm 0.18^{\mathrm{b}}$ & $8.81 \pm 0.19^{b}$ \\
\hline 1 & $46.77 \pm 0.73^{b}$ & $14.68 \pm 0.43^{b}$ & $2.45 \pm 0.18^{b}$ & $9.85 \pm 0.19^{\mathrm{c}}$ \\
\hline Time (min) & $\mathrm{p} \leq 0.01^{\dagger}$ & $\mathrm{p}=0.32^{\neq}$ & $\mathrm{p} \leq 0.24^{\not}$ & $\mathrm{p} \leq 0.01^{\dagger}$ \\
\hline 30 & $29.13 \pm 0.73^{\mathrm{a}}$ & $12.19 \pm 0.43^{\mathrm{a}}$ & $2.42 \pm 0.18^{\mathrm{a}}$ & $6.86 \pm 0.19^{\mathrm{a}}$ \\
\hline 45 & $39.09 \pm 0.73^{b}$ & $11.55 \pm 0.43^{\mathrm{a}}$ & $1.96 \pm 0.18^{\mathrm{a}}$ & $7.90 \pm 0.19^{b}$ \\
\hline 60 & $40.62 \pm 0.73^{b}$ & $12.51 \pm 0.43^{\mathrm{a}}$ & $2.13 \pm 0.18^{\mathrm{a}}$ & $8.43 \pm 0.19^{b}$ \\
\hline Time by $\mathrm{HCl}$ & $p \leq 0.01^{\dagger}$ & $p=0.01^{\dagger}$ & $p=0.75^{\ngtr}$ & $p \leq 0.01^{\dagger}$ \\
\hline $30 \mathrm{~min}, 0 \%$ & $18.03 \pm 1.29^{\mathrm{a}}$ & $7.25 \pm 0.83^{\mathrm{a}}$ & $1.61 \pm 0.31^{\mathrm{a}}$ & $4.39 \pm 0.22^{\mathrm{a}}$ \\
\hline $30 \mathrm{~min}, 0.5 \%$ & $32.29 \pm 1.29^{b}$ & $13.23 \pm 0.83^{b}$ & $3.07 \pm 0.31^{\mathrm{a}}$ & $8.13 \pm 0.22^{b}$ \\
\hline $30 \min , 1 \%$ & $37.06 \pm 1.29^{\mathrm{b}}$ & $16.1 \pm 0.83^{b}$ & $2.59 \pm 0.31^{\mathrm{a}}$ & $8.05 \pm 0.22^{\mathrm{b}}$ \\
\hline Grand Mean & $29.13 \pm 0.74$ & $12.19 \pm 0.48$ & $2.42 \pm 0.25$ & $6.86 \pm 0.13$ \\
\hline $45 \mathrm{~min}, 0 \%$ & $19.98 \pm 0.85^{\mathrm{a}}$ & $6.84 \pm 0.61^{\mathrm{a}}$ & $1.39 \pm 0.31^{\mathrm{a}}$ & $3.66 \pm 0.18^{\mathrm{a}}$ \\
\hline $45 \mathrm{~min}, 0.5 \%$ & $43.26 \pm 0.85^{\mathrm{b}}$ & $12.58 \pm 0.61^{\mathrm{b}}$ & $2.16 \pm 0.31^{\mathrm{a}}$ & $8.57 \pm 0.18^{\mathrm{b}}$ \\
\hline $45 \min , 1 \%$ & $54.03 \pm 0.85^{\mathrm{c}}$ & $15.22 \pm 0.61^{\mathrm{b}}$ & $2.34 \pm 0.31^{\mathrm{a}}$ & $11.48 \pm 0.18^{\mathrm{c}}$ \\
\hline Grand Mean & $39.09 \pm 0.49$ & $11.55 \pm 0.35$ & $1.97 \pm 0.07$ & $7.90 \pm 0.10$ \\
\hline $60 \mathrm{~min}, 0 \%$ & $23.87 \pm 1.55^{\mathrm{a}}$ & $9.43 \pm 0.76^{\mathrm{a}}$ & $1.57 \pm 0.31^{\mathrm{a}}$ & $5.54 \pm 0.51^{\mathrm{a}}$ \\
\hline $60 \mathrm{~min}, 0.5 \%$ & $48.76 \pm 1.55^{\mathrm{b}}$ & $15.38 \pm 0.76^{\mathrm{b}}$ & $2.38 \pm 0.31^{\mathrm{a}}$ & $9.73 \pm 0.51^{b}$ \\
\hline $60 \mathrm{~min}, 1 \%$ & $49.23 \pm 1.55^{b}$ & $12.71 \pm 0.76^{\mathrm{a}, \mathrm{b}}$ & $2.44 \pm 0.31^{\mathrm{a}}$ & $10.01 \pm 0.51^{\mathrm{b}}$ \\
\hline Grand Mean & $36.28 \pm 0.42$ & $12.08 \pm 0.25$ & $2.17 \pm 1.02$ & $7.73 \pm 0.11$ \\
\hline
\end{tabular}

\footnotetext{
* Results are expressed as mean \pm standard error in $\mathrm{mg} \mathrm{g}^{-1}$ dry matter of pomace

$\uparrow$ Significant at $p \leq 0.05$

${ }^{\star}$ Not significant $p>0.05$

Values with different letters are statistically different at $p \leq 0.05$
} 


\section{Influence of extraction parameters on concentrations of anthocyanins}

The average amount of anthocyanins in the grape skin extracts was $2.17 \pm 1.02 \mathrm{mg}$ Mvd-3-glc $\mathrm{g}^{-1}$ d.m. (Table 2). A recent study evaluating the influence of fermentation of grape pomace has reported similar values for anthocyanins under extraction, performed with hot water at $50{ }^{\circ} \mathrm{C}^{46}$. Further, lower concentrations were reported for grape marc from three different cultivars $0.87 \pm 0.06 \mathrm{mg}$ Mvd-3-glc/g d.m. ${ }^{42}$, but extraction was performed with $70 \%$ acetone $(\mathrm{v} / \mathrm{v})$ and $0.1 \% \mathrm{HCl}$ in an ultrasonic unit for $1 \mathrm{~h}$ at room temperature. Monrad et al. (2010) found two-fold higher concentrations of total anthocyanins in red grape pomace extracts $\left(4.36 \mathrm{mg} \mathrm{g}^{-1} \mathrm{~d} . \mathrm{m}\right.$. at $80{ }^{\circ} \mathrm{C}, 4.5 \mathrm{mg} \mathrm{g}^{-1} \mathrm{~d} . \mathrm{m}$. at $100{ }^{\circ} \mathrm{C}$, and $4.11 \mathrm{mg} \mathrm{g}^{-1}$ d.m. at $120^{\circ} \mathrm{C}$ ) in comparison with our results, but under accelerated solvent extraction (ASE). Also, it is well-known that anthocyanin quantities show large variations among different grape cultivars, e.g. in aqueous grape skin pomace extracts, the concentrations of anthocyanins varied from 1.76 to $21.40 \mathrm{mg} \mathrm{g}^{-1}$ d.m., while in aqueous alcohol extracts concentrations varied from 45.38 to $88.44 \mathrm{mg} \mathrm{g}^{-1}$ d.m. ${ }^{47}$. Concerning the influence of extraction parameters, anthocyanins amounts significantly increased with addition of $\mathrm{HCl}$, but remained the same for all extraction times. In addition, the cumulative influence of time and acidity was not significant, implying that extraction of anthocyanins is largely dependent on acidity (Table 2). This is likely due to the fact that anthocyanins are more stable in acidic solutions. Indeed, it was found that acidic aqueous solvents tend to be more useful for their extraction, which might be explained by the fact that the hydrolysis step helped the release of anthocyanins from plant cell walls ${ }^{48}$.

\section{Influence of extraction parameters on concentrations of flavonols}

Regarding the total content of flavonols, previously reported data confirmed significant variations between different vintage years for fermented grape skin with averages from 2.97 to $3.10 \mathrm{mg} \mathrm{g}^{-1} 49$. The amount of flavonols in our samples averaged $7.73 \pm 0.11 \mathrm{mg} \mathrm{QE} \mathrm{g}{ }^{-1} \mathrm{~d} . \mathrm{m}$. Similarly to the anthocyanins, it was reported that the results for flavonols tend to show large variations ${ }^{4}$. For instance, almost exactly the same values $\left(7.41 \pm 2.43 \mathrm{mg} \mathrm{g}^{-1}\right)$ as our results were obtained for evaluating flavonols in commercially available grape marc skin extracts ${ }^{50}$. This process employed hot water as solute, for 1-2 $h$ of extraction time. On the other hand, several-fold higher values were reported elsewhere $(52.7 \pm 5.0$ $\mathrm{mg}^{-1}$ ), likely due to the application of different extraction techniques ${ }^{42}$. From all the observed poly- phenols, and accordant with the favorable influence of acidity on their extraction ${ }^{14}$, flavonols showed the clearest influence of acidity on their recovery from grape skin pomace extracts (Table 2). The highest average experimental amounts of flavonols $\left(9.85 \pm 1.55 \mathrm{mg} \mathrm{g}^{-1}\right.$ d.m.) were detected if extraction time ranged between 45-60 minutes with $1 \% \mathrm{HCl}$ acidity (Table 2).

\section{Influence of extraction parameters on concentrations of total flavonoids}

Lastly, the average grand mean for total flavonoids was $36.28 \pm 0.42 \mathrm{mg} \mathrm{QE} \mathrm{g} \mathrm{g}^{-1}$ d.m. In comparison, previous values for pomace from three red

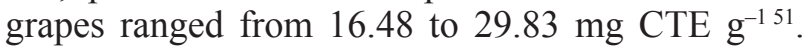
However, extraction was carried with $40 \%$ ethanol (v/v) as extraction solvent without addition of $\mathrm{HCl}$. Makris et al. (2007) evaluated agri-food solid waste extracts of white and red grape pomace, and the content of total flavonoids was 33.45 and $50.24 \mathrm{mg}$ CTE $\mathrm{g}^{-1}$, respectively (corrected for $5 \%$ of humidity). Extraction was carried out with $0.1 \% \mathrm{HCl}$ in methanol/acetone/water $(60 / 30 / 10, \mathrm{v} / \mathrm{v} / \mathrm{v})^{52}$. Addition of $\mathrm{HCl}$ resulted in increased flavonoid content, from 20.63 to $41.43(0.5 \% \mathrm{HCl})$ and $46.77 \mathrm{mg} \mathrm{QE}$ $\mathrm{g}^{-1}$ d.m. (1\% $\left.\mathrm{HCl}\right)$. The observed results confirmed that acidity had enhanced hydrolysis of polymeric phenolic structures and release of monomeric metabolites that are easier solubilized during extraction.

For all time intervals, increased acidity resulted with increased amounts of flavonoids (Table 2). Interestingly, with longer extraction time, the amounts of proanthocyanidins and anthocyanins remained similar, while total flavonoids on average increased $36.8 \%$ after extending extraction time from 30 minutes to 45 or 60 minutes (Table 2). Similarly, to our results, other sources have shown that higher total flavonoids concentrations were observed with longer extraction time (10 vs. $30 \mathrm{~min})$ for Inula helenium $^{53}$. Also, literature reports fluctuations (increase and decrease) in the flavonoid content as a function of time for aqueous ethanol extracts. It was hypothesized that increased time increased adhesion of diffused particles (flavonoid) around the cell walls of the supporting material (glass or plastic tubes) where extraction was conducted, which may hinder extraction ${ }^{54}$.

\section{Optimization of flavonoids recovery in red grape skin pomace extracts}

The quantities of all studied polyphenols were mutually strongly correlated, meaning that all of them strongly increased with each other (Table 3 ). To optimize the relation among proanthocyanidins (PC), anthocyanins (AC), flavonols (FL), total fla- 
vonoids (TF), extraction time, and acidity, the RSM regression models (quadratic, cubic etc.) were constructed. This approach was previously published by our group ${ }^{11,23,34,55-59}$. Significant models contained only statistically significant predictors (acidity, time, TF, and their various interactions). The constructed equations with RSM from experimental data were:

$$
\begin{aligned}
& \mathrm{PC}\left[\frac{\mathrm{mg}}{\mathrm{g} \mathrm{d} . \mathrm{m} .}\right]=4.70-0.40 \cdot t[\mathrm{~min}]+58.95 \cdot \operatorname{Acidity}[\%]+0.61 \cdot \mathrm{TF}\left[\frac{\mathrm{mg}}{\mathrm{g} \mathrm{d.m} .}\right]-0.51 \cdot t[\mathrm{~min}] \cdot \text { Acidity }[\%]+ \\
& +0.02 \cdot t[\mathrm{~min}] \cdot \mathrm{TF}\left[\frac{\mathrm{mg}}{\mathrm{gd} . \mathrm{m} .}\right]-1.98 \cdot \operatorname{Acidity}[\%] \cdot \mathrm{TF}\left[\frac{\mathrm{mg}}{\mathrm{gd} . \mathrm{m} .}\right]-0.02 \cdot \mathrm{TF}^{2}\left[\frac{\mathrm{mg}}{\mathrm{g} \mathrm{d} . \mathrm{m} .}\right]^{2}+ \\
& +0.03 \cdot \operatorname{Acidity}[\%] \cdot \ddot{u}^{2}\left[\frac{\mathrm{mg}}{\mathrm{g} \mathrm{d} . \mathrm{m} .}\right]^{2} \\
& \mathrm{AC}\left[\frac{\mathrm{mg}}{\mathrm{g} \mathrm{d} . \mathrm{m} .}\right]=-0.87+6.81 \cdot \operatorname{Acidity}[\%]+0.15 \cdot \mathrm{TF}\left[\frac{\mathrm{mg}}{\mathrm{g} \mathrm{d} . \mathrm{m} .}\right]-0.30 \cdot \operatorname{Acidity}[\%] \cdot \mathrm{TF}\left[\frac{\mathrm{mg}}{\mathrm{g} \mathrm{d} . \mathrm{m} .}\right] \\
& -0.002 \cdot \mathrm{TF}^{2}\left[\frac{\mathrm{mg}}{\mathrm{g} \mathrm{d} . \mathrm{m} .}\right]^{2}+0.003 \cdot \text { Acidity }[\%] \cdot \mathrm{TF}^{2}\left[\frac{\mathrm{mg}}{\mathrm{gd} \text { d.m. }}\right]^{2} \\
& \mathrm{FL}\left[\frac{\mathrm{mg}}{\mathrm{gd} . \mathrm{m} .}\right]=-14.31+1.66 \cdot t[\mathrm{~min}]+43.30 \cdot \operatorname{Acidity}[\%]-0.80 \cdot \mathrm{TF}\left[\frac{\mathrm{mg}}{\mathrm{g} \mathrm{d} . \mathrm{m} .}\right]-0.05 \cdot t^{2}\left[\mathrm{~min}^{2}\right]+ \\
& +0.04 \cdot t[\mathrm{~min}] \cdot \mathrm{TF}\left[\frac{\mathrm{mg}}{\mathrm{gd} . \mathrm{m} .}\right]-2.15 \cdot \text { Acidity }[\%] \cdot \mathrm{TF}\left[\frac{\mathrm{mg}}{\mathrm{g} \mathrm{d} . \mathrm{m} .}\right]+0.01 \cdot \mathrm{TF}^{2}\left[\frac{\mathrm{mg}}{\mathrm{g}}\right]^{2}+ \\
& +0.0004 \cdot t^{3}\left[\min ^{3}\right]-0.001 \cdot t[\min ] \cdot \mathrm{TF}^{2}\left[\frac{\mathrm{mg}}{\mathrm{g}}\right]^{2}+0.03 \cdot \operatorname{Acidity}[\%] \cdot \mathrm{TF}^{2}\left[\frac{\mathrm{mg}}{\mathrm{g}}\right]^{2}
\end{aligned}
$$

Model fitness (i.e. model efficacy) between experimental and modeled data was evaluated with adjusted $R_{\text {adj. }}^{2}$ which equaled $90.3 \%, 51.89 \%$, and $86.1 \%$ for equations $1-3$, respectively. Durbin-Watson statistic was insignificant and in the acceptable ranges from 1.4 to 2.6. Lack-of-fit tests for all models were insignificant, implying good fitness between modeled and experimental data. This also can be visually observed from Figure 1(d)-(f) for all extraction times and acidities in each group of flavonoids. Additionally, the occurrence of over-parameterization was tested with variance inflation factors that were all lower than the acceptable value (V.I.F. $\leq 4)$. In summary, all models were precise and with very good predictive power, and Figure 1 shows all RSM plots for all the flavonoids.

The highest amounts of $\mathrm{PC}=16.45 \mathrm{mg} \mathrm{g}^{-1} \mathrm{~d} . \mathrm{m}$. can be obtained from $35.54 \mathrm{TF}$ after 30.22 minutes of extraction and with addition of $0.99 \% \mathrm{HCl}$. The

\begin{tabular}{|c|c|c|c|c|}
\hline & $\begin{array}{l}\text { Proanthocyanidins } \\
{\left[\mathrm{mg} \mathrm{CE} \mathrm{g}^{-1} \text { d.m. }\right]}\end{array}$ & $\begin{array}{l}\text { Anthocyanins } \\
\text { [mg Mvd-3-glc } \\
\mathrm{g}^{-1} \text { d.m.] }\end{array}$ & $\begin{array}{l}\text { Total flavonoids } \\
{\left[\mathrm{mg} \mathrm{QE} \mathrm{g}{ }^{-1} \text { d.m.] }\right.}\end{array}$ & $\begin{array}{c}\text { Flavonols } \\
{\left[\mathrm{mg} \mathrm{QE} \mathrm{g}^{-1} \text { d.m. }\right]}\end{array}$ \\
\hline Proanthocyanidins [mg CE g ${ }^{-1}$ d.m.] & 1 & $0.77^{\dagger}$ & $0.82^{\dagger}$ & $0.85^{\dagger}$ \\
\hline Anthocyanins [mg Mvd-3-glc g-1 d.m.] & & 1 & $0.56^{\dagger}$ & $0.63^{\dagger}$ \\
\hline Total flavonoids [mg QE g ${ }^{-1}$ d.m.] & & & 1 & $0.96^{\dagger}$ \\
\hline Flavonols [mg QE g $\mathrm{g}^{-1}$ d.m.] & & & & 1 \\
\hline
\end{tabular}
optimal content of AC (3.74 $\mathrm{mg} \mathrm{g}^{-1}$ d.m.) can be obtained from $17.91 \mathrm{mg} \mathrm{g}^{-1}$ d.m. of $\mathrm{TF}$ at 42.04 minutes of extraction and with acidity of $1 \% \mathrm{HCl}$. In the same way, optimal amounts of FL $49.48 \mathrm{mg}$ $\mathrm{g}^{-1}$ d.m. can be obtained from $22.80 \mathrm{mg} \mathrm{g}^{-1}$ d.m. of $\mathrm{TF}$ at 49.48 minutes and with $0.86 \%$ of acidity.

Table 3 -Correlation among studied polyphenols

$\uparrow$ Significant at $p \leq 0.05$ 

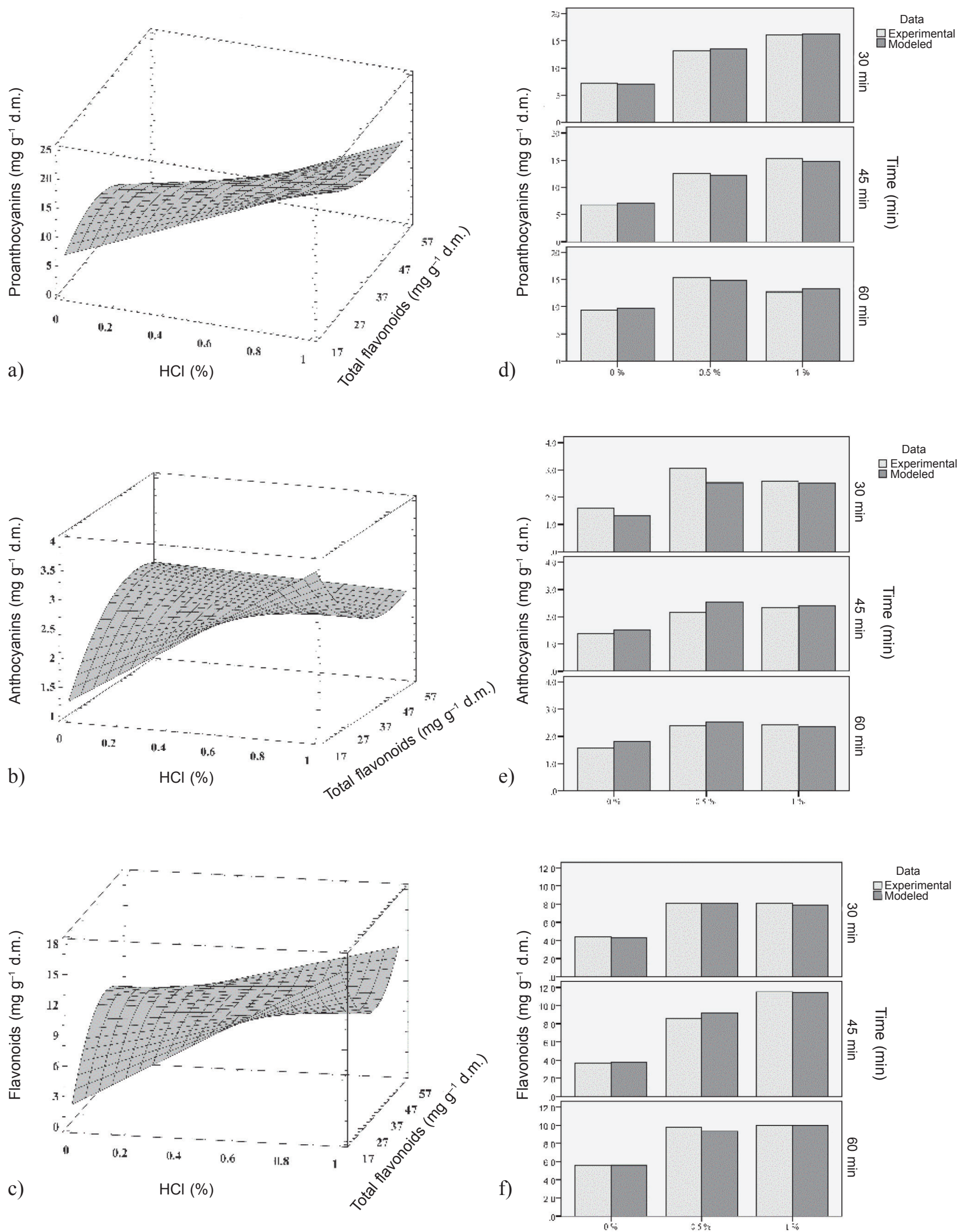

Fig. 1 - Graphs showing extraction conditions for flavonoids from red grape skin pomace extracts 
Equations $1-3$ can be applied for an industrial extraction of proanthocyanidins, anthocyanins and flavonols by controlling acidity, time, and concentrations of total flavonoids. For instance, it is a very common industrial scenario where a facility produces anthocyanins from grape pomace for further use (e.g. colorants or additives, antioxidants, nutraceuticals etc.) but the pomace has unknown content of such compounds. The amount of all polyphenols in different grape pomaces varies greatly, due to the influence of different cultivating conditions, vintages, cultivars, winemaking, etc. Hence, it is difficult to standardize industrial processing even for extraction of the same type of compounds, let alone for different ones. On the other hand, the goal of industry is to have steady production of the highest amounts of anthocyanins under optimal conditions that are derived from the lowest expenditure of resources and with flexibility of using the same pomace for different types of flavonoids. In such a situation, it is essential to know the content of anthocyanins for provided grape pomace in order to adjust the extraction/processing parameters in the facility and to evaluate the economic value of the pomace. This data can be obtained by spectrophotometric evaluation that has to be repeated over and over again for different polyphenols such as proanthocyanidins and flavonols. Therefore, a flexible economical approach is welcomed that is able to have the least number of analytical assessments for adjustment of the production. Here is where equations 1-3 could be useful. For example, for their solutions, only one spectrophotometric evaluation is needed, and that is the amounts of total flavonoids. It is reasonable to use this parameter since other mentioned polyphenols, in this instance proanthocyanidins and flavonols, are a subset of a set of total flavonoids. Thus, when pomace is delivered to the processing facility, one needs to evaluate only the amount of total flavonoids and if the goal is to produce anthocyanins, plug that data into equation 2 , together with the data for acidity and extraction time. That will provide the predicted maximum yield for the aforementioned pomace. If the same pomace is going to be used for the production of proanthocyanidins or flavonols, one can use the same data already obtained for the total flavonoids, and just use it in equation 1 or 3 .

\section{Conclusions}

The concentrations of all studied polyphenols (total flavonoids, proanthocyanidins, anthocyanins, flavonols) had increased with increasing acidity. Extraction time generally favored an increase in the studied polyphenols, but this relation was more evident for flavonols and total flavonoids, while less obvious for other examined phenolics. The flavonoid content in grape skin pomace extracts proved the interesting potential of grape pomace by-products as bioactive constituents in functional-foods production.

\section{ACKNOWLEDGMENTS}

This research was financed by the funds of the project "Application of innovative technologies in the isolation of bioactive compounds from organic waste in the wine production". The project is co-financed by the European Union from the European Regional Development Fund.

\section{References}

1. FAOSTAT-FAO, Statistical database. Accessed on August 8. 2016. http://www.fao.org. In 2016.

2. Schieber, A., Stintzing, F. C., Carle, R., By-products of plant food processing as a source of functional compounds - recent developments, Trends Food Sci. Tech. 12 (2001) 401. doi: https://doi.org/10.1016/S0924-2244(02)00012-2

3. Llobera, A., Cañellas, J., Dietary fibre content and antioxidant activity of Manto Negro red grape (Vitis vinifera) pomace and stem, Food Chem. 101 (2007) 659. doi: https://doi.org/10.1016/j.foodchem.2006.02.025

4. Kammerer, D. R., Kammerer, J., Valet, R., Carle, R., Recovery of polyphenols from the by-products of plant food processing and application as valuable food ingredients, Food Res. Int. 65 (2014) 2.

doi: https://doi.org/10.1016/j.foodres.2014.06.012

5. Voća, N., Krička, T., Brlek Savić, T., Matin, A., Jurišić, A., Organic waste after wine and olive oil production as raw material for thermal energy generation, PTEP-J Proces Energy Agric 14 (2010) 69.

6. Dominguez, J., Martinez-Cordeiro, H., Alvarez-Casas, M., Lores, $M$., Vermicomposting grape marc yields high quality organic biofertiliser and bioactive polyphenols, Waste Management \& Research 32 (2014) 1235. doi: https://doi.org/10.1177/0734242x14555805

7. Čukelj, N., Putnik, P., Novotni, D., Ajredini, S., Voučko, B., Duška, $C$., Market potential of lignans and omega-3 functional cookies, British Food Journal 118 (2016) 2420. doi: https://doi.org/10.1108/BFJ-03-2016-0117

8. Wang, C., Li, S., Functional Foods and Nutraceuticals Potential Role in Human Health. In Clinical Aspects of Functional Foods and Nutraceuticals, 1 ed.; Ghosh, D., Bagchi, D., Konishi, T., (Eds.), CRC Press: Boca Raton, 2015, pp 51-76.

9. Radovanović, V., Đekić, S., Radovanović, B., Economic potential of applying grape seed extract as a natural antioxidant, PTEP-J Proces Energy Agric. 15 (2011) 263.

10. Forbes-Hernandez, T. Y., Giampieri, F., Gasparrini, M., Mazzoni, L., Quiles, J. L., Alvarez-Suarez, J. M., Battino, $M$., The effects of bioactive compounds from plant foods on mitochondrial function: A focus on apoptotic mechanisms, Food Chem. Toxicol. 68 (2014) 154. doi: https://doi.org/10.1016/j.fct.2014.03.017

11. Bursać Kovačević, D., Putnik, P., Dragović-Uzelac, V., Vahčić, N., Babojelić Skendrović, M., Levaj, B., Influences of organically and conventionally grown strawberry culti- 
vars on anthocyanins content and color in purees and low-sugar jams, Food Chem. 181 (2015) 94. doi: https://doi.org/10.1016/j.foodchem.2015.02.063

12. Putnik, P., Bursać Kovačević, D., Penic, M., Dragovic-Uzelac, $V$., Optimizing microwave-assisted extraction parameters for polyphenols recovery from sage (Salvia officinalis L.), Ann. Nutr. Metab. 67 (2015) 523. doi: https://doi.org/10.1159/000440895

13. Santos-Buelga, C., Scalbert, A., Proanthocyanidins and tannin-like compounds - nature, occurrence, dietary intake and effects on nutrition and health, J. Sci. Food Agr. 80 (2000) 1094.

doi: https://doi.org/10.1002/(SICI)1097-0010(20000515)80 :7<1094::AID-JSFA569>3.0.CO;2-1

14. Harbourne, N., Marete, E., Christophe, J. J., O'Riordan, $D$., Conventional extraction techniques for phytochemicals. In Handbook of Plant Food Phytochemicals Sources, Stability and Extraction, Tiwari, B. K., Brunton, N. P., Brennan, C. S. (Ed.), John Wiley \& Sons, Ltd: Oxford, UK, 2013, Vol. 1, pp 399-453.

15. Ramirez-Lopez, L. M., McGlynn, W., Goad, C. L., DeWitt, C. A. M., Simultaneous determination of phenolic compounds in Cynthiana grape (Vitis aestivalis) by high performance liquid chromatography-electrospray ionisation-mass spectrometry, Food Chem. 149 (2014) 15. doi: https://doi.org/10.1016/j.foodchem.2013.10.078

16. Rockenbach, I. I., Rodrigues, E., Gonzaga, L. V., Caliari, V., Genovese, M. I., Goncalves, A. E. D. S., Fett, R., Phenolic compounds content and antioxidant activity in pomace from selected red grapes (Vitis vinifera L. and Vitis labrusca L.) widely produced in Brazil, Food. Chem. 127 (2011) 174. doi: https://doi.org/10.1016/j.foodchem.2010.12.137

17. Maier, T., Goppert, A., Kammerer, D. R., Schieber, A., Carle, R., Optimization of a process for enzyme-assisted pigment extraction from grape (Vitis vinifera L.) pomace, Eur. Food Res. Technol. 227 (2008) 267. doi: https://doi.org/10.1007/s00217-007-0720-y

18. Khanal, R. C., Howard, L. R., Prior, R. L., Procyanidin composition of selected fruits and fruit byproducts is affected by extraction method and variety, J. Agr. Food Chem. 57 (2009) 8839. doi: https://doi.org/10.1021/jf9015398

19. Bursać Kovačević, D., Putnik, P., Pedisić, S., Ježek, D., Karlovic, S., Dragovic-Uzelac, V., High hydrostatic pressure extraction of flavonoids from freeze-dried red grape skin as winemaking by-product, Ann. Nutr. Metab. 67 (2015) 521 doi: https://doi.org/10.1159/000440895

20. Dragović-Uzelac, V., Putnik, P., Zorić, Z., Ježek, D., Karlovic, S., Bursać Kovačević, D., Winery by-products: anthocyanins recovery from red grape skin by high hydrostatic pressure extraction (HHPE), Ann. Nutr. Metab. 67 (2015) 522. doi: https://doi.org/10.1159/000440895

21. Monrad, J. K., Howard, L. R., King, J. W., Srinivas, K., Mauromoustakos, A., Subcritical solvent extraction of anthocyanins from dried red grape pomace, J. Agr. Food Chem. 58 (2010) 2862. doi: https://doi.org/10.1021/jf904087n

22. Srinivas, K., King, J. W., Monrad, J. K., Howard, L. R., Zhang, D., Pressurized solvent extraction of flavonoids from grape pomace utilizing organic acid additives, Ital. J. Food Sci. 23 (2011) 90.

23. Putnik, P., Bursać Kovačević, D., Dragović-Uzelac, V., Optimizing acidity and extraction time for polyphenolic recovery and antioxidant capacity in grape pomace skin extracts with response surface methodology approach, J. Food Process Preserv. Accepted for publication (2016) doi: https://doi.org/10.1111/jfpp. 12710
24. Dudonne, S., Vitrac, X., Coutiere, P., Woillez, M., Merillon, $J$. M., Comparative study of antioxidant properties and total phenolic content of 30 plant extracts of industrial interest using DPPH, ABTS, FRAP, SOD, and ORAC assays, J. Agr. Food Chem. 57 (2009) 1768. doi: https://doi.org/10.1021/jf803011r

25. Vatai, T., Skerget, M., Knez, Z., Extraction of phenolic compounds from elder berry and different grape marc varieties using organic solvents and/or supercritical carbon dioxide, J. Food Eng. 90 (2009) 246. doi: https://doi.org/10.1016/j.jfoodeng.2008.06.028

26. Spigno, G., Trarnelli, L., De Faveri, D. M., Effects of extraction time, temperature and solvent on concentration and antioxidant activity of grape marc phenolics, J. Food Eng. 81 (2007) 200.

doi: https://doi.org/10.1016/j.jfoodeng.2006.10.021

27. Peralbo-Molina, A., Priego-Capote, F., de Castro, M. D. L., Comparison of extraction methods for exploitation of grape skin residues from ethanol distillation, Talanta 101 (2012) 292. doi: https://doi.org/10.1016/j.talanta.2012.09.028

28. Chang, C. C., Yang, M. H., Wen, H. M., Chern, J. C., Estimation of total flavonoid content in propolis by two complementary colorimetric methods, J. Food Drug Anal. 10 (2002) 178 .

29. Sun, B. S., Ricardo-da-Silva, J. M., Spranger, I., Critical factors of vanillin assay for catechins and proanthocyanidins, J. Agr. Food Chem. 46 (1998) 4267. doi: https://doi.org/10.1021/jf980366j

30. Giusti, M., M., Wrolstad, R., E., Characterization and measurement of anthocyanins by UV visible spectroscopy. In Current protocols in food analytical chemistry, Hoboken, NJ: John Wiley \& Sons, Inc.: 2001, pp F1.2.1-F1.2.13.

31. Howard, L. R., Clark, J. R., Brownmiller, C., Antioxidant capacity and phenolic content in blueberries as affected by genotype and growing season, J. Sci. Food Agr. 83 (2003) 1238 . doi: https://doi.org/10.1002/jsfa.1532

32. Putnik, P., Bursać Kovačević, D., Herceg, K., Pavkov, I., Zorić, Z., Levaj, B., Effects of modified atmosphere, anti-browning treatments and ultrasound on the polyphenolic stability, antioxidant capacity and microbial growth in fresh-cut apples, J. Food Process. Eng. Manuscript accepted for publication. (2016).

33. Granato, D., Calado, V. M. D., Jarvis, B., Observations on the use of statistical methods in Food Science and Technology, Food Res. Int. 55 (2014) 137. doi: https://doi.org/10.1016/j.foodres.2013.10.024

34. Bursać Kovačević, D., Putnik, P., Dragović-Uzelac, V., Pedisić, S., Režek Jambrak, A., Herceg, Z., Effects of cold atmospheric gas phase plasma on anthocyanins and color in pomegranate juice, Food Chem. 190 (2016) 317. doi: https://doi.org/10.1016/j.foodchem.2015.05.099

35. Duba, K. S., Casazza, A. A., Ben Mohamed, H., Perego, P., Fiori, L., Extraction of polyphenols from grape skins and defatted grape seeds using subcritical water: Experiments and modeling, Food Bioprod. Process 94 (2015) 29. doi: https://doi.org/10.1016/j.fbp.2015.01.001

36. Gonzalez-Centeno, M. R., Comas-Serra, F., Femenia, A., Rossello, C., Simal, S., Effect of power ultrasound application on aqueous extraction of phenolic compounds and antioxidant capacity from grape pomace (Vitis vinifera L.): Experimental kinetics and modeling, Ultrason. Sonochem. 22 (2015) 506. doi: https://doi.org/10.1016/j.ultsonch.2014.05.027 
37. Pedroza, M. A., Amendola, D., Maggi, L., Zalacain, A., De Faveri, D. M., Spigno, G., Microwave-assisted extraction of phenolic compounds from dried waste grape skins, Int. J. Food Eng. 11 (2015) 359. doi: https://doi.org/10.1515/ijfe-2015-0009

38. Plazibat, V., Bursać Kovačević, D., Putnik, P., Jukic, M. Tranfić Bakić, M., Dragović-Uzelac, V., The effect of Microwave Assisted Extraction (MAE) on the isolation of Polyphenols from Hawthorn, Ann. Nutr. Metab. 67 (2015) 527. doi: https://doi.org/10.1159/000440895

39. Barba, F. J., Puértolas, E., Brncic, M., Panchev, I. N., Dimitrov, D. A., Athès-Dutour, V., Emerging Extraction. In Food Waste Recovery Processing Technologies and Industrial Techniques, Galanakis, C. M. (Ed.), Elsevier, London, 2014, pp 249-272.

40. Barba, F. J., Galanakis, C. M., Esteve, M. J., Frigola, A. Vorobiev, E., Potential use of pulsed electric technologies and ultrasounds to improve the recovery of high-added value compounds from blackberries, J. Food Eng. 167 (2015) 38 . doi: https://doi.org/10.1016/j.jfoodeng.2015.02.001

41. Yilmaz, Y., Toledo, R. T., Oxygen radical absorbance capacities of grape/wine industry byproducts and effect of solvent type on extraction of grape seed polyphenols, J. Food Compos. Anal. 19 (2006) 41. doi: https://doi.org/10.1016/j.jfca.2004.10.009

42. Deng, Q., Penner, M. H., Zhao, Y. Y., Chemical composition of dietary fiber and polyphenols of five different varieties of wine grape pomace skins, Food Res. Int. 44 (2011) 2712. doi: https://doi.org/10.1016/j.foodres.2011.05.026

43. Price, M. L., Van Scoyoc, S., Butler, L. G., A critical evaluation of the vanillin reaction as an assay for tannin in sorghum grain, J. Agr. Food Chem. 26 (1978) 1214.

44. Zhu, Q. Y., Holt, R. R., Lazarus, S. A., Ensunsa, J. L., Hammerstone, J. F., Schmitz, H. H., Keen, C. L., Stability of the flavan-3-ols epicatechin and catechin and related dimeric procyanidins derived from cocoa, J. Agr. Food Chem. 50 (2002) 1700 . doi: https://doi.org/10.1021/jf011228o

45. Ky, I., Lorrain, B., Kolbas, N., Crozier, A., Teissedre, P. L., Wine by-products: phenolic characterization and antioxidant activity evaluation of grapes and grape pomaces from six different french grape varieties, Molecules 19 (2014) 482. doi: https://doi.org/10.3390/molecules 19010482

46. Vergara-Salinas, J. R., Bulnes, P., Zuniga, M. C., Perez-Jimenez, J., Torres, J. L., Mateos-Martin, M. L., Agosin, E., Perez-Correa, J. R., Effect of pressurized hot water extraction on antioxidants from grape pomace before and after enological fermentation, J. Agr. Food Chem. 61 (2013) 6929. doi: https://doi.org/10.1021/jf4010143

47. Ky, I., Teissedre, P. L., Characterisation of Mediterranean grape pomace seed and skin extracts: polyphenolic content and antioxidant activity, Molecules 20 (2015) 2190. doi: https://doi.org/10.3390/molecules20022190

48. Mateus, N., Freitas, V., Anthocyanins as food colorants. In Anthocyanins: Biosynthesis, Functions, and Applications, Gould, K., Davies, K., Winefield, C. (Eds.), Springer Verlag: New York, 2009, pp 283-304.
49. Barcia, M. T., Pertuzatti, P. B., Gomez-Alonso, S., Godoy, H. T., Hermosin-Gutierrez, I., Phenolic composition of grape and winemaking by-products of Brazilian hybrid cultivars BRS Violeta and BRS Lorena, Food Chem. 159 (2014) 95 . doi: https://doi.org/10.1016/j.foodchem.2014.02.163

50. Polyphenolics Inc., Revised Notification of GRAS Determination for MegaNaturalTM Gold Grape Seed Extract (GSE) and Grape Skin Extract (GSKE) Use in Beverage Products: GRAS Exemption Claim. In Nutrition, C. f. F. S. a. A., Ed. U. S. Food and Drug Administration: Washington] DC, 2003, p 99.

51. Iora, S. R. F., Maciel, G. M., Zielinski, A. A. F., da Silva, M. V., Pontes, P. V. D., Haminiuk, C. W. I., Granato, D., Evaluation of the bioactive compounds and the antioxidant capacity of grape pomace, Int. J. Food Sci. Tech. 50 (2015) 62 . doi: https://doi.org/10.1111/ijfs.12583

52. Makris, D. P., Boskou, G., Andrikopoulos, N. K., Polyphenolic content and in vitro antioxidant characteristics of wine industry and other agri-food solid waste extracts, J. Food Compos. Anal. 20 (2007) 125. doi: https://doi.org/10.1016/j.jfca.2006.04.010

53. Wang, J., Zhao, Y. M., Guo, C. Y., Zhang, S. M., Liu, C. L., Zhang, D. S., Bai, X. M., Ultrasound-assisted extraction of total flavonoids from Inula helenium, Pharmacogn Mag. 8 (2012) 166. doi: https://doi.org/10.4103/0973-1296.96581

54. Felicetti, M. A., Piantino, F., Coury, J. R., Aguiar, M. L., Influence of removal time and particle size on the particle substrate adhesion force, Braz. J. Chem. Eng. 25 (2008) 71. doi: https://doi.org/10.1590/S0104-66322008000100009

55. Obranović, O., Škevin, D., Kraljić, K., Pospišil, M., Neđeral, N., Blekić, M., Putnik, P., Influence of climate, varieties and production process on tocopherols, plastochromanol-8 and pigments in flaxseed oil, Food Technol. Biotech. 54 (2015) 496. doi: https://doi.org/10.17113/ftb.53.04.15.4252

56. Putnik, P., Bursac Kovacevc, D., Penić, M., Fegě̌, M., Dragovic-Uzelac, $V$., Microwave-assisted extraction (MAE) of Dalmatian sage leafs for the optimal yield of polyphenols: HPLC-DAD identification and quantification, Food Anal. Method 9 (2016) 2385. doi: https://doi.org/10.1007/s12161-016-0428-3

57. Putnik, P., Bursać Kovačević, D., Herceg, K., Levaj, B., Influence of respiration on predictive microbial growth of Aerobic mesophilic bacteria and Enterobacteriaceae in fresh-cut apples packaged under modified atmosphere, J. Food Safety, (2016) Accepted for publication. doi: https://doi.org/10.1111/jfs.12284

58. Bursać Kovačevć, D., Kljusurić, J. G., Putnik, P., Vukušić, T., Herceg, Z., Dragovic-Uzelac, V., Stability of polyphenols in chokeberry juice treated with gas phase plasma, Food Chem. 212 (2016) 323. doi: https://doi.org/10.1016/j.foodchem.2016.05.192

59. Putnik, P., Bursac Kovacevc, D., Fresh-cut apples spoilage and predictive microbial growth under modified atmosphere packaging. In Food Safety and Protection, Rai, R., Aswathanarayan, J. B. (Eds.), CRC Press Press, Boca Raton, FL., 2017, p 504. 